\title{
Effect of Potassium and Zinc Solubilizing Microorganism on Nutrient Uptake and Microbial Population of Mungbean
}

\author{
R.I. Navsare*, S.S. Mane and K.D. Mahorkar \\ Department of Soil Science and Agricultural Chemistry, College of Agriculture, Badnapur, \\ Vasantrao Naik Marathwada Krishi Vidyapeeth, Parbhani 431402 (M.S.), India \\ *Corresponding author
}

\section{A B S T R A C T}

\section{Keywords}

Mungbean, Nutrient uptake, Microbial population, $\mathrm{KSB}, \mathrm{ZnSB}$

Article Info

Accepted:

07 January 2018

Available Online:

10 February 2018
A Field experiment was conducted in kharif season 2016-17 at experimental farm of Department of Soil Science and Agricultural Chemistry, College of Agriculture, Badnapur using mungbean as a test crop to studies on effect of potassium and zinc solubilizing microorganism on nutrient uptake and microbial population of mungbean. The experiment was laid out on Vertisols with five treatment combination, replicated four times in randomized block design. The treatment consists of $\mathrm{T}_{1}$ Absolute control (No fertilizer application), $\mathrm{T}_{2} \mathrm{RDF}$ (25:50:00 N, $\mathrm{P}_{2} \mathrm{O}_{5}$ and $\left.\mathrm{K}_{2} \mathrm{O} \mathrm{ha}^{-1} \mathrm{~kg} \mathrm{ha}^{-1}\right), \mathrm{T}_{3}(\mathrm{RDF}+$ Rhizobium + $\mathrm{PSB}+\mathrm{KSB}), \mathrm{T}_{4}(\mathrm{RDF}+$ Rhizobium $+\mathrm{PSB}+\mathrm{KSB}+\mathrm{ZSB}), \mathrm{T}_{5}(\mathrm{RDF}+$ Rhizobium + PSB + $\mathrm{KSB}+\mathrm{ZSB})$. The results emerged out clearly indicated that various microbial population like, actinomycets, fungi and bacteria was increased due to application of potassium and zinc solubilizing microorganism. It was inferred from the results that application RDF + Rhizobium + PSB + KSB + ZSB $\left(\mathrm{T}_{5}\right)$ found superior over control application. The KSB and ZSB application showed synergistic effects on other nutrients (N, P, K, Zn, Fe) uptake. Soil fertility was also found to be improved due to application of potassium and zinc solubilizing microorganism to mungbean.

\section{Introduction}

India is one of the major pulses growing country of the world, accounting roughly for one third of total world area under pulse cultivation and one fourth of total world production. Pulses occupy a key position in Indian diet and meet about 30 per cent of the daily protein requirement. Green gram commonly known as "mung" or "mung bean" is the most important crop of the South-East Asia and particularly the Indian sub-continent.
This popular and ancient crop is specially recognized as an excellent source of protein. It also plays an important role in maintaining and improving the fertility of soil through its ability to fix atmospheric nitrogen in the soil by root nodules.

Potassium is one of the essential nutrient for plant growth and vital for sustaining modern high yield agriculture. Plant needs large quantities of potassium which not only improves the crop yield, but crop quality also. 
Hence potassium fertilization results in higher value product and therefore in a greater return to farmers. It is a prime factor for deciding the market price of green gram grown, which improve the income of farmers just by improving the quality of produce (Krishna, 1995).

Among the micronutrients, zinc plays vital role in plant growth and development. Zinc also catalyses the biosynthesis of indol acetic acid, acting as metal activator of the enzyme, there by ultimately increasing crop yield. Moreover, it controls the equilibrium between $\mathrm{CO}_{2}$, water and carbonic acid in plant metabolism and helps in synthesis of nucleic acids, proteins and stimulates seed formation. Its deficiency retards photosynthesis and nitrogen metabolism. The end result is lower yield; poor produce quality and sub optimal nutrient use efficiency. Mungbean also respond to zinc application.

\section{Materials and Methods}

A field experiment was conducted during kharif season 2016-2017 to entitled "Studies on effect of potassium and zinc solubilizing microorganism on mungbean" at Departmental farm of Soil Science and Agriculture Chemistry, College of Agriculture, Badnapur. The details of materials used and methods adopted during the course of present investigation are explained in this chapter with appropriate heads.

The experimental soil had clay structure, moderately calcareous in nature and slightly alkaline in reaction, normal in salt content. Before sowing, initial soil sample is collected randomly from $0-30 \mathrm{~cm}$ depth covering experimental area which was analysed for various physico-chemical characteristics. An experiment was laid out in Randomized Block Design with four replication and five treatments. Treatments consisted of absolute control (no fertilizer application) $\left(\mathrm{T}_{1}\right), \mathrm{RDF}$ $\left(25: 50: 00 \mathrm{~N}, \mathrm{P}_{2} \mathrm{O}_{5}, \mathrm{~K}_{2} \mathrm{O} \mathrm{kg} \mathrm{ha}{ }^{-1}\right)\left(\mathrm{T}_{2}\right),(\mathrm{RDF}+$ Rhizobium + $\mathrm{PSB}+\mathrm{KSB})\left(\mathrm{T}_{3}\right),(\mathrm{RDF}+$ Rhizobium + PSB + KSB + ZSB $)\left(\mathrm{T}_{4}\right),(\mathrm{RDF}$ + Rhizobium $+\mathrm{PSB}+\mathrm{KSB}+\mathrm{ZSB})\left(\mathrm{T}_{5}\right)$.

Mungbean variety BM 2002-1 was selected for sowing. The germination test was carried out before sowing. The sowing was done at spacing $30 \mathrm{~cm}$ X $10 \mathrm{~cm}$. Gap filling was done, wherever it is necessary to maintain the plant population in each plot.

Periodical intercultural operations like thinning and weeding were carried out and plots were maintain for good crop growth.

\section{Nutrient uptake}

Nutrient uptake i.e. uptake of N, P, K, Zn and $\mathrm{Fe}$ was calculated by considering grain and dry matter yield at harvest in particular treatment plot in relation concentration of the particular nutrient in respective treatment plot using the formula.

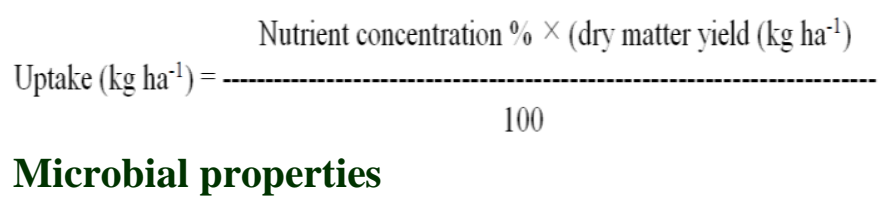

For isolation of bacteria, fungi and actinomycetes from soil. Three different media were used for specific group of flora namely, Nutrient Agar medium (For Bacteria), Ken knight medium (For Actinomycetes) and Potato Dextrose Agar Media (For Fungi).

Dilution plate technique is one of the most popular methods for isolation and enumeration of soil fungi, actinomycetes and bacteria as follows.

\section{Results and Discussion}

\section{Nutrient uptake (N, P, K, Zn, Fe)}

The data shown in the Table 1 revealed that, 
application of $\mathrm{RDF}+$ Rhizobium $+\mathrm{PSB}+$ $\mathrm{KSB}+\mathrm{ZSB}\left(\mathrm{T}_{5}\right)$ recorded higher $\mathrm{N}, \mathrm{P}, \mathrm{K}, \mathrm{Zn}$ and Fe uptake than the application of Absolute control (No fertilizer application) (T1) only. Highest total uptake of $\mathrm{N}\left(258.66 \mathrm{~kg} \mathrm{ha}^{-1}\right), \mathrm{P}$ (24.84 kg ha $\left.{ }^{-1}\right), \mathrm{K}\left(62.19 \mathrm{~kg} \mathrm{ha}^{-1}\right), \mathrm{Zn}$ (186.39 $\left.\mathrm{g} \mathrm{ha}^{-1}\right)$ and Fe $\left(1038.38 \mathrm{~g} \mathrm{ha}^{-1}\right)$ in mungbean was recorded followed by RDF + Rhizobium + $\mathrm{PSB}+\mathrm{KSB}+\mathrm{ZSB}\left(\mathrm{T}_{4}\right)$ and $\mathrm{RDF}+$ Rhizobium $+\mathrm{PSB}+\mathrm{KSB}\left(\mathrm{T}_{3}\right)$. In presence of potassium, the increase in $\mathrm{N}$ uptake could be attributed to enhanced vigour of crop growth with increased utilization and translocation of $\mathrm{N}$ in to plant and synergy between $\mathrm{N}$ and $\mathrm{K}$ in soil system resulting in the enhancement of yield. This might be due to application of higher doses of mineral $\mathrm{K}$ favored higher root and shoot development which might have also increased the K uptake.

Similar, result was observed by Tiwari D.D. et al.,(2012) in pigeon pea and mustard. Singh and Manohar (1982) found the foliar application of $\mathrm{ZnSO}_{4}$ was most effective in improving the protein content of grain and increasing uptake of $\mathrm{N}$ and $\mathrm{P}$ by mungbean. The increasing $\mathrm{Fe}$ uptake may also be attributed due to concentration of $\mathrm{Fe}$ in plant and seed. Significant increase in biomass production is also one of the reasons for better nutrient uptake. Similar trend was observed by Chaturvedi et al., (2010) in soybean.

\section{Microbial population (Bacteria, Fungi, Actinomycetes)}

The scrutiny of the data is given in Table 2 . Shows significant increase in microbial population in soil after harvest of mungbean crop was also noted with single as well as dual inoculation with Rhizobium, KSB and $\mathrm{ZnSB}$ along with recommended dose of fertilizers over control. Significantly highest value of bacterial population $\left(39.78 \mathrm{CFU} \times 10^{-7}\right)$, fungal population $\left(23.29 \mathrm{CFU} \times 10^{-5}\right)$, actinomycetes population $\left(7.51 \mathrm{CFU} \times 10^{-4}\right)$ were noted in $\mathrm{RDF}+$ Rhizobium + PSB + KSB + ZSB $\left(\mathrm{T}_{5}\right)$.

Table.1 N, P, K, Zn and Fe uptake as influenced by various treatments

\begin{tabular}{|c|c|c|c|c|c|c|c|c|c|c|c|c|c|c|c|}
\hline \multirow{2}{*}{ Treatments } & \multicolumn{3}{|c|}{ N uptake $\left(\mathrm{kg} \mathrm{ha}^{-1}\right)$} & \multicolumn{3}{|c|}{ P uptake $\left(\mathrm{kg} \mathrm{ha}^{-1}\right)$} & \multicolumn{3}{|c|}{ K uptake (kg ha-1) } & \multicolumn{3}{|c|}{ Zn uptake (g ha-1) } & \multicolumn{3}{|c|}{ Fe uptake $\left(\mathrm{g} \mathrm{ha}^{-1}\right)$} \\
\hline & Plant & Seed & Total & Plant & Seed & Total & Plant & Seed & Total & Plant & Seed & Total & Plant & Seed & Total \\
\hline$T_{1}($ Control) & 19.99 & 49.68 & 69.67 & 4.33 & 2.12 & 6.45 & 6.50 & 10.66 & 17.16 & 36.68 & 30.34 & 67.02 & 340.50 & 93.48 & 433.98 \\
\hline ( Only RDF ) & 46.64 & 103.08 & 149.72 & 8.40 & 4.20 & 12.60 & 16.27 & 21.04 & 37.30 & 51.50 & 42.18 & 93.68 & 530.75 & 150.78 & 681.53 \\
\hline $\begin{array}{l}\mathrm{T}_{3}(\mathrm{RDF}+ \\
\text { Rhizobium + } \\
\text { PSB + KSB })\end{array}$ & 62.60 & 141.32 & 203.92 & 9.77 & 7.54 & 17.31 & 20.77 & 25.64 & 50.04 & 64.89 & 54.27 & 119.16 & 626.50 & 208.45 & 834.95 \\
\hline $\begin{array}{l}\text { T }_{4}(\mathrm{RDF}+ \\
\text { Rhizobium + } \\
\text { PSB + KSB + } \\
\text { ZSB) }\end{array}$ & 87.05 & 133.14 & 220.19 & 10.42 & 9.34 & 19.76 & 26.86 & 29.29 & 57.07 & 85.55 & 69.94 & 155.49 & 667.25 & 242.21 & 909.46 \\
\hline $\begin{array}{l}\text { T }_{5}(\mathrm{RDF}+ \\
\text { Rhizobium + } \\
\text { PSB + KSB + } \\
\text { ZSB })\end{array}$ & 106.83 & 151.83 & 258.66 & 12.63 & 12.21 & 24.84 & 28.94 & 32.99 & 62.19 & 100.42 & 85.97 & 186.39 & 758.0 & 280.38 & 1038.38 \\
\hline SEm \pm & 0.77 & 1.54 & 0.77 & 0.31 & 0.13 & 0.54 & 0.38 & 0.44 & 0.85 & 1.26 & 1.60 & 2.37 & 4.41 & 3.40 & 6.23 \\
\hline C.D. (at $5 \%$ ) & 2.39 & 4.76 & 2.39 & 0.97 & 0.42 & 1.17 & 1.18 & 1.38 & 2.54 & 3.9 & 4.95 & 5.13 & 13.61 & 10.50 & 17.54 \\
\hline
\end{tabular}


Table.2 Microbial population after harvest of mungbean as influenced by various treatments

\begin{tabular}{|c|c|c|c|}
\hline Treatments & $\begin{array}{c}\text { Bacteria } \\
\left(\mathrm{CFU} \times \mathbf{1 0}^{-\mathbf{7}}\right)\end{array}$ & $\begin{array}{l}\text { Actinomycetes } \\
\left(\text { CFU } \times 10^{-5}\right)\end{array}$ & $\begin{array}{c}\text { Fungi } \\
\left(\mathrm{CFU} \times \mathbf{1 0}^{-4}\right)\end{array}$ \\
\hline $\mathbf{T}_{1}$ (Control) & 30.81 & 16.71 & 4.75 \\
\hline $\mathbf{T}_{2}$ ( Only RDF ) & 33.99 & 20.09 & 6.11 \\
\hline $\mathrm{T}_{3}(\mathrm{RDF}+$ Rhizobium + PSB + KSB $)$ & 36.58 & 21.64 & 7.12 \\
\hline $\begin{array}{l}\mathrm{T}_{4}(\mathrm{RDF}+\text { Rhizobium + PSB + KSB } \\
+\mathrm{ZSB})\end{array}$ & 37.83 & 22.14 & 7.16 \\
\hline $\begin{array}{l}\mathrm{T}_{5}(\mathrm{RDF}+\text { Rhizobium }+\mathrm{PSB}+\mathrm{KSB} \\
+\mathrm{ZSB})\end{array}$ & 39.78 & 23.29 & 7.51 \\
\hline SEm \pm & 0.49 & 0.24 & 0.10 \\
\hline C.D. (at $5 \%$ ) & 1.51 & 0.75 & 0.33 \\
\hline
\end{tabular}

Karande and Khot (2007) noted that the Rhizobium and potassium recorded significantly more total microbial count at harvest than that of $100 \%$ RDF. Combination of Rhizobium inoculation with levels of zinc increased VAM fungi colonization. Similar findings were reported by Mandhre et al., (1995).

It can be concluded that significantly highest uptake of $(\mathrm{N}, \mathrm{P}, \mathrm{K}, \mathrm{Zn}, \mathrm{Fe})$ was deliberated with treatment of fertilizer consisting recommended dose of fertilizer with potassium and zinc solubilizer application. Potassium and zinc application showed synergic effects on other nutrient uptake and soil fertility was improved due to application of potassium and zinc to the mungbean. Significant increase in microbial population in soil after harvest of mungbean crop was also noted with single as well as dual inoculation with Rhizobium, KSB and $\mathrm{ZnSB}$ along with recommended dose of fertilizers over control.

\section{References}

Chaturvedi. S, Chandel, A.S, Dhyani, V.C, Singh, A. P. (2010) Productivity, profitability and quality of soybean (Glycine max) and residual soil fertility as influenced by integrated nutrient management. Indian $J$. Agron., 55(2) :133-137.

Karande, S.V and Khot, R.B. (2007) Effect of field layouts and integrated nutrient management on nutrient balance studies in Kabuli chickpea. J. Maharashtra agric. Univ., 32(3): 416-418.

Krishna S. Mineral Nutrition of Plants: Principles and perspectives. Better Crops. 1995; 82(3): 155-160.

Mandhre, V. K, Kalbhore, H. B, Patil, P. L. (1995). Effect of VAM, Rhizobium and phosphorus on summer groundnut. $J$. Maharashtra agric. Univ., 20(2): 261-262.

Singh, G and Manohar, R. S. (1982) Study on the uptake of nitrogen and phosphorus by green gram and the quality of crop as affected by phosphorus levels and foliar spray of $\mathrm{H}_{2} \mathrm{SO}_{4}$ and micronutrient. Indian $\mathrm{J}$. Agric. Res., 16(4): 219-222.

Tiwari, D.D., Pandey, S.B. and Dubey, M.K. (2012). Effect of potassium application on yield and quality characteristics of pigeon pea (Cajanus cajan) and mustard (Brassica juncea L. Czern) crops in Central Plain Zone of Uttar Pradesh. International Potash Institute. e-ifc (Electronic International Fertilizer Correspondent)., 3: 16-24.

\section{How to cite this article:}

Navsare, R.I., S.S. Mane and Mahorkar, K.D. 2018. Effect of Potassium and Zinc Solubilizing Microorganism on Nutrient Uptake and Microbial Population of Mungbean. Int.J.Curr.Microbiol.App.Sci. 7(02): 682-685. doi: https://doi.org/10.20546/ijcmas.2018.702.085 